\title{
AVIFAUNA OF LAKE GEČA - PILOT FAUNISTIC AND SEROLOGICAL STUDY
}

\author{
Danielová, P. ${ }^{1}$, Korytár, L. ${ }^{1}$, Csank, T. ${ }^{2}$ \\ ${ }^{1}$ Department of the Environment, Veterinary Legislation and Economy \\ University of Veterinary Medicine and Pharmacy, Komenského 73, 04181 Košice \\ ${ }^{2}$ Department of Microbiology and Immunology \\ University of Veterinary Medicine and Pharmacy, Komenského 73, 04181 Košice \\ Slovakia
}

lubos.korytar@uvlf.sk

\section{ABSTRACT}

Lake Geča is located in the northern part of the Protected Bird Territory Košická kotlina. With a surface area of 250 ha it is the largest water area in the complex of a number of gravel lake areas located close to the villages Čaňa and Geča. From 2014-2016 we used the method of capture and ringing to focus on observations of transmigrating passerine birds species. This pilot study included serological testing of selected passerine species for the presence of specific antibodies to Usutu virus (USUV) by the virus neutralization test. During the field research we obtained 1077 data about ringed birds of 43 species. We received one report about the presence of a bird ringed in our study from another location in Slovakia, and 3 long distance (above $100 \mathrm{~km}$ ) reports from Hungary, Czechia and Croatia. No specific antibodies against USUV were detected in the birds tested.

Key words: avifauna; Geča; bird-ringing; Usutu virus

\section{INTRODUCTION}

The Important Bird Area (IBA) Košická basin is an important territory from the point of view of the occurrence of many species of free living birds. In this territory there are several valuable locations important for the birds that use these locations throughout the year.

Lake Geča is included in the land registries of the villages Geča, Čaňa and Nižná Myšla, located south of Košice in eastern Slovakia. With a surface area of 250 ha it is the largest water area in the complex of a number of Gravel Lake areas located close to Košice, recorded in the land registries of the above mentioned villages.

In some places, the banks of the lake are bordered with extensive littoral growth with reeds and the important admixture of invasive herbs, particularly Canadian Goldenrod (Solidago canadensis) and Giant Goldenrod (Solidago gigantea). Such biotopes with dense bank growth provide good shelter and protection for the birds and provide an abundant food supply.

Currently, gravel and sand are extracted actively from Lake Geča by means of extraction boats. The vertical pro- 
file of banks that are formed during the extraction is used by numerous populations of Sand Martins (Riparia riparia) - hundreds of pairs and European Bee-eater (Merops apiaster) - tens of pairs. Bank cavities primarily produced by these two species are used in the breeding period and also by other cavity nesters, such as Eurasian Tree Sparrow (Passer montanus), Common starling (Sturnus vulgaris), and Northern Wheatear (Oenanthe oenanthe).

From the point of view of migration, bird species can be classified as migratory, partially migratory and permanent residents that do not migrate. Climatic seasonality, interspecies and intraspecies competition are among the most important factors responsible for avian migratory behaviour. Abundance of food is characteristic of summer months while in winter the food resources are scarce. Most birds migrate before the nesting period to places where there are relatively sufficient food resources and favourable temperatures [6].

Our nesting species from the families Sylviidae and Acrocephalidae are long-distance migratory birds and the essential part of their migratory flight takes place at night [2].

Sufficient knowledge about migratory birds is important from the point of view of protection of the health of humans and other animals as they may serve as reservoirs and natural hosts of pathogens and thus play an important role in epizootic cycles [10]. With regard to evolution, humans are less closely related to birds than to mammals and because of that, birds are less responsible for the transmission of zoonotic pathogens [4]. However, due to their active flying abilities and migration they are able to transfer pathogens over long distances [7].

Usutu virus (USUV) belongs the family Flaviviridae, causing flavivirus infections.

The life cycle of USUV is very similar to other members of the Japanese encephalitis serocomplex [1].

In Africa USUV circulates among birds and mosquitoes while mammals serve as occasional hosts. It has a zoonotic character and humans become infected after being bitten by an infected mosquito. Humans are dead-end hosts of this virus $[3,8]$.

Arthropods, particularly mosquitoes (Culex), are vectors of USUV. Free living birds have a high potential to distribute pathogenic micro-organisms [12].

Recently, USUV has been isolated also from bats in Germany. Detection of USUV in bats raises a question of the potential role of bats as a reservoir of the virus in Africa and its transmission by mosquitoes, which merits further research [1].

In the past, USUV was not considered a potential threat to humans as it has not been associated with death or severe disease in humans or other animals and has not been detected outside of tropical and subtropical Africa [12].

In 2001, the USUV caused the deaths of a large number of Blackbirds (Turdus merula) in Vienna, Austria. Bird watchers also reported clinically sick blackbirds exhibiting signs of apathy and ruffled feathers. A massive mortality of Barn Swallows (Hirundo rustica) was observed in Austria too. [13].

Up to now, no systematic research has been carried out in the area of Lake Geča that focused on observations of individual bird species and the dynamics of migration of small passerine birds. The aim of our study was to obtain relevant information about species spectrum of migrating passerine birds and thus contribute to the knowledge of the migration of birds in the IBA Košická basin. Another aim was to carry out serological testing for the presence of antibodies to USUV.

\section{MATERIALS AND METHODS}

\section{Capture of birds and sample collection}

The capture of birds and collection of samples were carried out on the basis of exemption from the Act No.543/2002 of the Code on protection of nature and countryside, granted to trained members of the Slovak Ornitological Society/Bird Life Slovakia by the Ministry of the environment of the Slovak Republic.

The birds were trapped only by the permitted method using mist-nets.

We tested the method of night trapping of migrating passerines focusing on the species of the genera: Acrocephalus, Locustella, Luscinia and Sylvia. The night trapping was conducted during spring and autumn migrations.

During the night migration flight, the birds were attracted by means of a high performance MP3 players.

The samples of blood used for obtaining serum from the selected group of passerine birds were obtained from the vena jugularis.

\section{Serological examination}

Serological examination of blood serum for the pres- 
ence of antibodies to USUV was carried out by the microtitration serum-virus neutralization test. The avian sera were inactivated at $56^{\circ} \mathrm{C}$ for $30 \mathrm{~min}$ and diluted $1: 10$ with Eagle's Minimum Essential Medium (EMEM). Duplicate dilutions of samples in EMEM were prepared in $25 \mu \mathrm{l}$ volumes. To each sample we added the equivalent volumes of 100 TCID50 viral strains WNV 578/10 and USUV 939/01 (kindly provided by Prof. Norbert Nowotny, University of Veterinary Medicine in Vienna, Austria). Each serum sample was subjected to cytotoxicity checking by adding $25 \mu \mathrm{l}$ of EMEM medium instead of the virus. After a 1-hour incubation at $37^{\circ} \mathrm{C}$, we added to each sample, $50 \mu \mathrm{l}$ of $10 \%$ EMEM solution with antibiotics, containing $1 \times 104$ Vero E6 cells. Microtitration plates were incubated at $37^{\circ} \mathrm{C}$ for 5 days under $5 \% \mathrm{CO}_{2}$.

\section{RESULTS}

During 2014, we obtained information about 556 trapped and ringed birds belonging to 36 species (Table 1).

In the years 2015 and 2016, we trapped and recorded 284 and 232 birds, mostly passerines (Tables 2 and 3).

Of the number we ringed 229 birds that belonged to 24 species, 3 of them were local birds that were retrapped after the previous marking.

We received four retrospective reports about birds ringed within our study from other locations. A Western Yellow Wagtail (Motacilla flava), ringed in 2014, was trapped by a bird ringer in the location of Perín ponds in the same year; Sedge Warbler (Acrocephalus schoenobae$n u s$ ), ringed in the autumn of 2014, was checked by a ringer in the following season in Szeged, Hungary, $277 \mathrm{~km}$ away from lake Geča. Savi's Warbler (Locustella luscinioides),

Table 1. Birds ringed in 2014

\begin{tabular}{lcll}
\hline \multicolumn{1}{c}{ Species } & Ringed & \multicolumn{1}{c}{ Species } & Ringed \\
\hline Acrocephalus arundinaceus & 1 & Motacilla flava & 21 \\
Acrocephalus palustris & 43 & Parus major & 96 \\
Acrocephalus scirpaceus & 25 & Passer domesticus & 7 \\
Acrocephalus schoenobaenus & 30 & Passer montanus & 83 \\
Aegythalos caudatus & 11 & Phoenicurus ochruros & 2 \\
Carduelis cannabina & 12 & Phylloscopus collybita & 50 \\
Carduelis carduelis & 9 & Phylloscopus sibilatrix & 6 \\
Cyanistes caeruleus & 51 & Phylloscopus trochilus & 2 \\
Emberiza schoeniclus & 8 & Prunella modularis & 8 \\
Erithacus rubecula & 1 & Remiz pendulinus & 2 \\
Ficedula albicollis & 1 & Riparia riparia & 17 \\
Hippolais icterina & 1 & Serinus serinus & 3 \\
Hirundo rustica & 1 & Sturnus vulgaris & 1 \\
Chloris chloris & 3 & Sylvia atricapilla & 24 \\
Lanius collurio & 3 & Sylvia borin & 4 \\
Locustella luscinioides & 2 & Sylvia communis & 16 \\
Luscinia megarhynchos & 2 & Sylvia curruca & 4 \\
Merops apiaster & 7 & Sylvia nisoria & 1 \\
\hline & & & 2 \\
\hline
\end{tabular}

Source: An original table 
Table 2. Birds ringed in 2015

\begin{tabular}{lclc}
\hline \multicolumn{1}{c}{ Species } & Ringed & \multicolumn{1}{c}{ Species } & Ringed \\
\hline Acrocephalus arundinaceus & 15 & Merops apiaster & 1 \\
Acrocephalus palustris & 93 & Parus major & 3 \\
Acrocephalus scirpaceus & 34 & Passer montanus & 14 \\
Acrocephalus schoenobaenus & 35 & Phylloscopus collybita & 5 \\
Carduelis cannabina & 1 & Phylloscopus sibilatrix & 2 \\
Carduelis carduelis & 2 & Phylloscopus trochilus & 4 \\
Coturnix coturnix & 1 & Remiz pendulinus & 11 \\
Cyanistes caeruleus & 10 & Riparia riparia & 1 \\
Emberiza schoeniclus & 3 & Sylvia atricapilla & 13 \\
Ficedula albicollis & 1 & Sylvia borin & 2 \\
Chloris chloris & 1 & Sylvia communis & 15 \\
Ixobrychus minutus & 1 & Sylvia curruca & 4 \\
Lanius collurio & 1 & Sylvia nisoria & 3 \\
Locustella fluviatilis & 2 & Turdus merula & 1 \\
Locustella luscinioides & 3 & Turdus philomelos & 1 \\
Luscinia megarhynchos & 1 & & \\
\hline & & & \\
\hline
\end{tabular}

Source: An original table

Table 3. Birds ringed in 2016

\begin{tabular}{lclc}
\hline \multicolumn{1}{c}{ Species } & Ringed & \multicolumn{1}{c}{ Species } & Ringed \\
\hline Acrocephalus arundinaceus & 1 & Passer montanus & 4 \\
Acrocephalus palustris & 37 & Phylloscopus collybita & 4 \\
Acrocephalus scirpaceus & 17 & Phylloscopus sibilatrix & 1 \\
Acrocephalus schoenobaenus & 14 & Phylloscopus trochilus & 1 \\
Cyanistes caeruleus & 13 & Remiz pendulinus & 3 \\
Emberiza schoeniclus & 2 & Sturnus vulgaris & 1 \\
Ixobrychus minutus & 1 & Sylvia atricapilla & 74 \\
Locustella luscinioides & 5 & Sylvia borin & 22 \\
Locustella naevia & 3 & Sylvia communis & 9 \\
Luscinia luscinia & 2 & Sylvia curruca & 5 \\
Luscinia megarhynchos & 4 & Turdus merula & 1 \\
Parus major & 2 & Turdus philomelos & 3 \\
\hline
\end{tabular}

Source: An original table 
ringed in the autumn of 2015, was found alive in the following year during nesting season in Březina, Czech Republic, location, $500 \mathrm{~km}$ away. A Great Reed Warbler (Acrocephalus arundinaceus), ringed at lake Geča in 2015, was trapped by ornithologists during a direct migration flight in Croatia, at Vransko jezero lake, $686 \mathrm{~km}$ from Geča, only 14 days following the ringing.

A selected group of passerine birds trapped during 2016 was tested for the presence of antibodies to USUV: Great Reed Warbler (Acrocephalus arundinaceus) $(\mathrm{n}=1)$; Marsh Warbler (Acrocephalus palustris) $(\mathrm{n}=10)$, Eurasian Reed Warbler (Acrocephalus scirpaceus) $(\mathrm{n}=10)$; Sedge Warbler (Acrocephalus schoenobaenus) $(\mathrm{n}=3)$; Eurasian Blackcap (Sylvia atricapilla) $(\mathrm{n}=31)$; Thrush Nightingale (Luscinia luscinia) $(\mathrm{n}=2)$; Common Nightingale (Luscinia megarhynchos) $(\mathrm{n}=3)$; Eurasian Tree Sparrow (Passer montanus) $(\mathrm{n}=1)$; Garden Warbler (Sylvia borin) $(\mathrm{n}=6)$; Whitethroat (Sylvia communis) $(\mathrm{n}=5)$; Lesser Whitethroat (Sylvia curruca) $(\mathrm{n}=2)$; and Song Thrush (Turdus obscurus) $(\mathrm{n}=2)$.

\section{DISCUSSION}

The primary results of trapping and ringing obtained in 2014 indicated that the investigated location plays an important role in the migration of diverse species and spectrum of passerine birds.

It is well known that the European species of the genera Acrocephalus, Sylvia and Locustella, wintering in subSaharean Africa, belong primarily to night migrants $[9,11]$. The species of these genera may be attracted during their migratory night flights by strong light sources (reflectors, lighthouses and similar) and identically, during the day, by playing the recordings of the corresponding bird species [5].

The second of the above mentioned phenomena was tested successfully, as it attracted birds flying over our location and allowed us to trap them in impact nets at selected trapping points.

We gained primary experience with such night trapping focusing specifically on acrocephalid warblers (A. palustris, A. scirpaceus, A. schoenobaenus and A. arundinaceus) and Locustella (L. fluviatilis, L. luscinioides) at lake Geča during the 2015 trapping season.
An interesting experience was the entrapment of an adult female of Little Bittern (I. minutus). On the basis of this and related visual observation we can confirm the view that birds of this species can be successfully attracted during night hours by sounds of Acrocephalus spectrum.

We consider it a success that we were able to confirm assumption from the previous season (2014) that the investigated location is a part of a migration corridor of our rare species of the Barred Warbler (S. nisoria), as indicated by successful trapping and ringing of 3 juvenile specimens.

In 2016, we successfully used Acrocephalus sounds to trap in complete darkness another juvenile Little Bittern.

USUV has not yet been isolated from birds in the Slovak territory. A part of our survey was the serological testing of lake Geča avifauna for the presence of specific antibodies to USUV. For this purpose we subjected the selected group of birds to virus neutralisation test and confirmed the absence of this virus in the investigated location.

Recently, USUV was isolated from bats in Germany. This detection of USUV in bats raises a question that should be addressed in future research including the potential role of bats as reservoirs in Africa and the transmission of USUV by mosquitoes [1] Our examination failed to confirm seropositivity of birds from the selected group of passerine birds.

\section{CONCLUSIONS}

During 2014-2016 we carried out the first systematic monitoring of avifauna so far of the ontologically non-investigated lake Geča location. During field investigation we obtained 1077 data about trapped and ringed birds belonging to 43 species.

We received four retrospective reports from other locations about birds ringed during our study.

The presence of specific antibodies to USUV was not confirmed in any of the samples of passerine birds.

\section{ACKNOWLEDGEMENT}

The study was carried out within the work on the project VEGA 1/0729/16. 


\section{REFERENCES}

1. Ashraf, U., Ye, J., Ruan, X., Wan, S., Zhu, B., Cao, S., 2015: Usutu virus: An emerging flavivirus in Europe. Viruses, 7 , 219-238.

2. Berthold, P., 1993: Bird Migration: A General Survey. Oxford University Press, Oxford, 239 pp.

3. Buckley, A., Dawson, A., Moss, R.S., Hinsley, S.A., Bellamy, P.E., Gould, E. A., 2003: Serological evidence of West Nile virus, Usutu virus and Sindbis virus infection of birds in the UK. Journal of General Virology, 84, 2807-2817.

4. Cleaveland, S., Laurenson, M.K., Taylor, L.H., 2001: Diseases of humans and their domestic mammals: pathogen characteristics, host range and the risk of emergence. Philos. Trans. Roy. Soc. Lond., B, Biol. Sci., 356, 1411.

5. Kennerley, P., Pearson, D., 2010: Reed and Bush Warblers. London, Helm, 28-30.

6. Klvaňa, P., 2008: Bird migration (In Czech). In Cepák, J., et al. (Eds.): Atlas of Migration of Birds of Czech and Slovak Republics (In Czech). Aventinum, Prague, 8-15.

7. Kruse, H., Kirkemo, A. M., Hendeland, K., 2004: Wildlife as source of zoonotic infections. Emerg. Infect. Dis., 10, 20672072
8. Mackenzie, J. S., Gubler, J. D., Peterson, L. R., 2004: Emerging flaviviruses: the spread and resurgence of Japanese encephalitis, West Nile and dengue viruses. Nature Medicine Supplement, 10, 98-109.

9. Newton, I., 2008: The Migration Ecology of Birds. London, Academic Press, 976 pp.

10. Reed, K.D., Meece, J.K., Henkel, J.S., Shukla, S. K., 2003: Birds, migration and emerging zoonoses: West Nile Virus, Lyme disease, influenza A and enteropathogens. J. Clin. Med. Res., 1, 5-12.

11. Shirihai, H., Gargallo, G., Helbig, A.J., 2015: Sylvia Warblers. Identification, Taxonomy and Phylogeny of the Genus Sylvia. London, Christopher Helm, 576 pp.

12. Vázques, A., Jiménez-Clavero, M.A., Franco, L., DonosoMantke, O., Sambri, V., Niedrig, M., et al., 2011: Usutu virus - potential risk of human disease in Europe. EuroSurveillance, 16, $5 \mathrm{pp}$.

13. Weissenböck, H., Mannsberger, S. CH., Bakonyi, T., Nowotny, N., 2007: Emergence of Usutu virus in Central Europe: diagnosis, surveillance and epizootiology. In Takken, W., Knols, B. G. J. (Eds.): Emerging Pests and Vector-borne Diseases in Europe. Wageningen Academic Publishers, The Netherlands 153-168.

Received, October 3, 2017

Accepted, December 12, 2017 